\title{
Prevention of intraventricular haemorrhage by fresh frozen plasma
}

\author{
D W BEVERLEY, T J PITTS-TUCKER, P J CONGDON, R J ARTHUR, AND G TATE \\ Departments of Paediatrics, Radiology, and Haematology, General Infirmary at Leeds
}

\begin{abstract}
SUmmaRY Seventy three preterm infants weighing less than $1500 \mathrm{~g}$ or less than 32 weeks' gestation, or both, were allocated randomly to treatment (fresh frozen plasma $10 \mathrm{ml} / \mathrm{kg}$ on admission and at 24 hours of age) or control groups. Fifteen $(41 \%)$ out of 37 control patients sustained intraventricular haemorrhage compared with five $(14 \%)$ of 36 patients receiving treatment $\left(\chi^{2}=5 \cdot 24, P=0 \cdot 022\right)$. No difference was found in coagulation factors measured at birth or at 48 hours of age in both groups. Fresh frozen plasma appears to have a beneficial effect in the prevention of intraventricular haemorrhage.
\end{abstract}

Intraventricular haemorrhage is the most common neurological disorder in preterm infants, occurring in $30-40 \%$ of babies weighing less than $1500 \mathrm{g.}^{1-3}$ Defects in haemostasis have been associated with the occurrence of intraventricular haemorrhage, ${ }^{+6}$ and intervention studies have produced equivocal results. $^{7-9}$ These studies, however, were performed before the advent of cranial ultrasound when diagnosis was based on clinical grounds and necropsies. As infants with major intraventricular haemorrhage are at high risk of neurological handicap we conducted a randomised prospective controlled trial using fresh frozen plasma to investigate its effectiveness in preventing intraventricular haemorrhage.

\section{Patients and methods}

Each year the Regional Neonatal Unit at Leeds General Infirmary admits about 120 infants of low birthweight (less than $1500 \mathrm{~g}$ ), of whom half are inborn. All infants weighing less than $1500 \mathrm{~g}$ or less than 32 weeks' gestation, or both, were considered to be eligible for the study.

On admission each child was given vitamin $\mathrm{K} 1 \mathrm{mg}$ intramuscularly, and a cranial ultrasound was performed to exclude an early intraventricular haemorrhage. Each infant was allocated to a treatment or control group by the opening of a presealed envelope that randomised allocation to study groups. Blood was taken for coagulation studies, and the infants assigned to the treatment group were given fresh frozen plasma $10 \mathrm{ml} / \mathrm{kg}$ on admission and again at 24 hours of age. In both groups coagulation studies were repeated at 48 hours of age. It was not possible to perform coagulation studies on all infants because of sampling and technical difficulties.

Ultrasound scans were repeated in all infants at age 48 hours, age 7-10 days, and before discharge home. Additional scans were performed when clinically warranted; thus in all children who died scans were performed shortly before death. The scans at 7-10 days and subsequent scans were performed by a radiologist (RJA) who had no knowledge of the clinical state of the infants. When haemorrhages were identified serial scans were performed at regular intervals to grade the maximum extension of the haemorrhage according to Papile's classification. ${ }^{10}$

All infants were given vitamin $E$ from birth as prophylaxis against retrolental fibroplasia, ${ }^{11}$ and any infant with an unstable intra-arterial blood pressure trace, as described by Perlman, ${ }^{12}$ was paralysed with pancuronium.

Collection of blood and coagulation studies. Blood samples $(2 \mathrm{ml})$ were collected from most infants on admission at the time of insertion of an indwelling umbilical arterial catheter or if this was not possible, by radial artery puncture. Half of the blood sample was anticoagulated with trisodium citrate and used to determine the prothrombin time (Manchester Comparative Reagent), activated partial thromboplastin time (General Diagnostics Automated APTT Reagent), and fibrinogen concentration (clot opacity method). A further $0.5 \mathrm{ml}$ was added to thrombin and aprotinin before the detection of fibrin and fibrinogen degradation products. The remaining $0.5 \mathrm{ml}$ was anticoagulated with edetic acid and used to determine the platelet count and mean 
platelet volume with a Coulter counter model $\mathrm{S}+\mathrm{IV}$. A further $2 \mathrm{ml}$ blood sample was taken at age 48 hours and treated similarly.

Ultrasound studies. The occurrence of intraventricular haemorrhage was detected with a portable real time ATL ultrasound sector scanner with a $5 \mathrm{MHz}$ probe by methods described previously. ${ }^{13}$

\section{Results}

During December 1983 to August 1984, 85 babies weighing less than $1500 \mathrm{~g}$ or less than 32 weeks' gestation, or both, were admitted to the neonatal intensive care unit. For administrative reasons five babies were not included in the study and seven were withdrawn from the analysis of the results (two treatment and five control patients; Table 1). The remaining 73 patients form the basis of our report.

No significant difference was found between the treatment group and control group in birthweight, gestational age, and other clinical factors that have been associated with the development of intraventricular haemorrhage (Table 2). Five of 36 infants in the treatment group, however, developed intraventricular haemorrhage compared with 15 of 37 control patients $\left(\chi^{2}=5 \cdot 24, P=0.022\right.$, Yates's correction, 1 df) (Table 3). Furthermore, if the seven patients who were excluded from the study are included in the analysis the degree of significance is increased. We were unable to show any difference in the coagulation studies undertaken on admission and at 48 hours of age in both groups (Table 4). We noticed a consistent trend for infants with intraventricular haemorrhage to have a longer prothrombin time, longer partial thromboplastin time, and increased fibrin/fibrinogen degradation products at birth and at 48 hours than children without haemorrhage, though this trend was not significant.
Table 2 Clinical data on treatment and control groups*

\begin{tabular}{lll}
\hline & $\begin{array}{l}\text { Control } \\
\text { group } \\
(n=37)\end{array}$ & $\begin{array}{l}\text { Treatment } \\
\text { group } \\
(n=36)\end{array}$ \\
\hline Mean (SD) gestation (weeks) & $28 \cdot 75(2 \cdot 05)$ & $29 \cdot 36(2 \cdot 36)$ \\
Mean (SD) weight (g) & $1 \cdot 216(0 \cdot 32)$ & $1 \cdot 246(0 \cdot 40)$ \\
Mean (SD) Apgar score at 1 min & $6 \cdot 1(2 \cdot 3)$ & $4 \cdot 9(2 \cdot 9)$ \\
Mean (SD) Apgar score at 5 min & $8 \cdot 2(2 \cdot 0)$ & $7 \cdot 5(2 \cdot 0)$ \\
Vertex delivery (\%) & $11(30)$ & $11(31)$ \\
Inborn (\%) & $19(51)$ & $23(64)$ \\
Respiratory distress syndrome (\%) & $28(76)$ & $24(67)$ \\
Ventilation (\%) & $31(84)$ & $29(81)$ \\
Arterial carbon dioxide tension & $10(27)$ & $9(25)$ \\
$>8 K P a(\%) \dagger$ & $9(24)$ & $7(19)$ \\
pH<7.15 (\%)† & & $26 \cdot 7(7 \cdot 2)$ \\
Mean (SD) maximum peak airway & $26 \cdot 7(7 \cdot 9)$ & $0 \cdot 69(0 \cdot 25)$ \\
pressure (mm $\left.\mathrm{H}_{2} \mathrm{O}\right)$ & $0 \cdot 65(0 \cdot 25)$ & $7(19)$ \\
Mean (SD) maximum $\mathrm{F}_{\mathrm{I}} \mathrm{O}_{2}$ & $9(24)$ & $10(28)$ \\
Pneumothorax (\%) & $9(24)$ & $20(56)$ \\
Patent ductus arteriosus (\%) & $21(57)$ & \\
Paralysed (\%) &
\end{tabular}

*All differences between groups not significant.

+Occurrence on one or more occasion of these values on arterial gas sampling.

Table 3 Occurence and severity of intraventricular haemorrhage

\begin{tabular}{llll}
\hline $\begin{array}{l}\text { Grade of intraventricular } \\
\text { haemorrhage }\end{array}$ & $\begin{array}{l}\text { Control group } \\
(n=37)\end{array}$ & $\begin{array}{l}\text { Treatment group } \\
(n=36)\end{array}$ \\
\hline I & 4 & 2 & \\
II & 3 & 0 & \\
III & 6 & 3 & \\
IV & 2 & 0 & $\chi^{2}=5 \cdot 24^{*}$ \\
\hline Total & 15 & 5 & $P=0 \cdot 022^{*}$ \\
\hline
\end{tabular}

*Yates's correction $1 \mathrm{df}$.

The mean (SD) volume of crystalloid that the treatment and control groups received on the first day of life $(72.8(19.1) \mathrm{ml} / \mathrm{kg} /$ day and $68.7(16.2)$ $\mathrm{ml} / \mathrm{kg} /$ day) and second day of life (84.5 (16.3) $\mathrm{ml} / \mathrm{kg} /$ day and $82.1(16 \cdot 6) \mathrm{ml} / \mathrm{kg} /$ day) were similar. The treatment group received $10.4(0.68) \mathrm{ml} / \mathrm{kg} /$ day

Table 1 Clinical details of patients withdrawn from study

\begin{tabular}{|c|c|c|c|c|}
\hline Study group & $\begin{array}{l}\text { Gestation } \\
\text { (weeks) }\end{array}$ & $\begin{array}{l}\text { Weight } \\
\text { (g) }\end{array}$ & Reason for withdrawal & Outcome \\
\hline Treatment & 26 & 750 & Died at 6 hours, before fresh frozen plasma given & Died age 6 hours Grade IV intraventricular haemorrhage \\
\hline Treatment & 29 & 1050 & Intraventricular haemorrhage on admission & Died age 4 days Grade III intraventricular haemorrhage \\
\hline Control & 26 & 950 & $\begin{array}{l}\text { Severe disseminated intravascular coagulation } \\
\text { secondary to intraventricular haemorrhage at } \\
24 \text { hours treated with fresh frozen plasma }\end{array}$ & $\begin{array}{l}\text { Grade III intraventricular haemorrhage. } \\
\text { Discharged home }\end{array}$ \\
\hline Control & 31 & 1100 & $\begin{array}{l}\text { Severe hypotension treated with fresh frozen plasma } \\
\text { to maintain blood pressure }\end{array}$ & $\begin{array}{l}\text { Grade III intraventricular haemorrhage. } \\
\text { Discharged home }\end{array}$ \\
\hline Control & 25 & 800 & $\begin{array}{l}\text { Severe hypotension treated with fresh frozen plasma } \\
\text { to maintain blood pressure }\end{array}$ & $\begin{array}{l}\text { No intraventricular haemorrhage } \\
\text { Discharged home. Retrolental fibrohyperplasia }\end{array}$ \\
\hline Control & 32 & 1400 & $\begin{array}{l}\text { Severe hypotension treated with fresh frozen plasma } \\
\text { to maintain blood pressure }\end{array}$ & $\begin{array}{l}\text { No intraventricular haemorrhage } \\
\text { Discharged home }\end{array}$ \\
\hline Control & 29 & 970 & $\begin{array}{l}\text { Severe disseminated intravascular haemorrhage at } \\
36 \text { hours treated with fresh frozen plasma }\end{array}$ & $\begin{array}{l}\text { No intraventricular haemorrhage } \\
\text { Discharged home }\end{array}$ \\
\hline
\end{tabular}


Table 4 Coagulation studies on admission and at age 48 hours (mean (SD))

\begin{tabular}{|c|c|c|c|c|c|c|}
\hline & $\begin{array}{l}\text { Prothrombin } \\
\text { time (secs) }\end{array}$ & $\begin{array}{l}\text { Activated partial } \\
\text { thromboplastin } \\
\text { time (secs) }\end{array}$ & Fibrinogen $(g / l)$ & $\begin{array}{l}\text { No of patients with } \\
\text { fibrinogen degradation } \\
\text { products }>10 \mathrm{mg} / \mathrm{l}\end{array}$ & $\begin{array}{l}\text { Platelet count } \\
\left(10^{9} / l\right)\end{array}$ & $\begin{array}{l}\text { Mean platelet } \\
\text { volume fll }\end{array}$ \\
\hline \multicolumn{7}{|c|}{ Control group $(n=37)$} \\
\hline Admission & $\begin{array}{l}22 \cdot 4(5 \cdot 6) \\
(n=33)\end{array}$ & $\begin{array}{l}61 \cdot 5(28 \cdot 8) \\
(n=33)\end{array}$ & $\begin{array}{l}1.36(0.99) \\
(n=22)\end{array}$ & $\begin{array}{l}2 \\
(n=27)\end{array}$ & $\begin{array}{l}223(156) \\
(n=30)\end{array}$ & $\begin{array}{l}8 \cdot 1(0 \cdot 7) \\
(n=24)\end{array}$ \\
\hline 48 hours & $\begin{array}{l}18 \cdot 8(4 \cdot 3) \\
(n=25)\end{array}$ & $\begin{array}{l}48 \cdot 6(16 \cdot 1) \\
(n=25)\end{array}$ & $\begin{array}{l}1.28(0.65) \\
(n=22)\end{array}$ & $\begin{array}{l}2 \\
(n=26)\end{array}$ & $\begin{array}{l}194(84 \cdot 3) \\
(\mathrm{n}=27)\end{array}$ & $\begin{array}{l}8 \cdot 8(1 \cdot 8) \\
(n=21)\end{array}$ \\
\hline $\begin{array}{l}\text { Mean change } \\
\text { from admission } \\
\text { to } 48 \text { hours }\end{array}$ & $\begin{array}{l}-3.96(5 \cdot 2) \\
(n=25)\end{array}$ & $\begin{array}{l}-10 \cdot 23(34 \cdot 1) \\
(n=25)\end{array}$ & $\begin{array}{l}-0.08(0.77) \\
(n=20)\end{array}$ & $\begin{array}{l}-0.42(3.0) \\
(n=24)\end{array}$ & $\begin{array}{l}-23 \cdot 8(147 \cdot 8) \\
(n=26)\end{array}$ & $\begin{array}{l}0 \cdot 36(0 \cdot 47) \\
(n=20)\end{array}$ \\
\hline \multicolumn{7}{|c|}{ Treatment group $(n=36)$} \\
\hline Admission & $\begin{array}{l}20 \cdot 5(5 \cdot 2) \\
(n=28)\end{array}$ & $\begin{array}{l}58 \cdot 6(25 \cdot 3) \\
(n=28)\end{array}$ & $\begin{array}{l}0.95(0.61) \\
(n=20)\end{array}$ & $\begin{array}{l}4 \\
(n=26)\end{array}$ & $\begin{array}{l}206(96 \cdot 5) \\
(n=28)\end{array}$ & $\begin{array}{l}8 \cdot 6(2 \cdot 3) \\
(n=17)\end{array}$ \\
\hline 48 hours & $\begin{array}{l}19 \cdot 1(5 \cdot 2) \\
(n=22)\end{array}$ & $\begin{array}{l}48 \cdot 0(12 \cdot 5) \\
(n=22)\end{array}$ & $\begin{array}{l}1 \cdot 42(0 \cdot 80) \\
(n=18)\end{array}$ & $\begin{array}{l}1 \\
(n=20)\end{array}$ & $\begin{array}{l}183(78 \cdot 4) \\
(n=21)\end{array}$ & $\begin{array}{l}9.0(2.3) \\
(n=14)\end{array}$ \\
\hline $\begin{array}{l}\text { Mean charge } \\
\text { from admission } \\
\text { to } 48 \text { hours }\end{array}$ & $\begin{array}{l}-0.95(5.9) \\
(n=21)\end{array}$ & $\begin{array}{l}-7.05(17 \cdot 7) \\
(n=21)\end{array}$ & $\begin{array}{l}+0.39(0.50) \\
(n=17)\end{array}$ & $\begin{array}{l}-0 \cdot 21(8 \cdot 16) \\
(n=19)\end{array}$ & $\begin{array}{l}-13.9(96.4) \\
(n=21)\end{array}$ & $\begin{array}{l}-0.23(0.49) \\
(n=14)\end{array}$ \\
\hline
\end{tabular}

fresh frozen plasma during the first 24 hours of life and $10.6(0.69) \mathrm{ml} / \mathrm{kg} /$ day on the second day. None of the control patients received fresh frozen plasma during the study period, though three were given small volumes of purified protein fraction during the first 24 hours of life to help maintain their blood pressures. The treatment patients who were inborn received their fresh frozen plasma at a mean (SD) age of $2.9(1.3)$ hours whereas those who were not inborn received their fresh frozen plasma at 8.9 (4.8) hours. No difference was found between the mean age of recruitment into the trial of the treatment and control patients.

Thirteen infants died during our study; five were from the treatment group, two of whom sustained intraventricular haemorrhage. Four of the deaths from the treatment group occurred before 48 hours of age, and one of these infants had developed an intraventricular haemorrhage. In the control group eight infants died: five died before $\mathbf{4 8}$ hours of age, three of whom had developed intraventricular haemorrhages. Three infants from the control group died after 48 hours of age; two had developed intraventricular haemorrhages. Necropsies were undertaken in seven infants who died, and in these the diagnosis by ultrasound was confirmed.

We were unable to detect any adverse effects of our treatment; the incidence of patent ductus arteriosus, congestive cardiac failure, and necrotising enterocolitis was similar in the two groups. Two infants developed asymptomatic hypoglycaemia during infusion of fresh frozen plasma, but each responded with an intravenous infusion of $10 \%$ dextrose. Subsequently, we gave fresh frozen plasma in addition to maintenance fluids to prevent hypoglycaemia.

\section{Discussion}

Recent reports have described the potential beneficial effects of phenobarbitone, ${ }^{14}$ sodium ethamsylate, ${ }^{15}$ and vitamin $\mathrm{E}^{16}$ as prophylaxis for the prevention of intraventricular haemorrhage. Reports of the use of fresh frozen plasma have provided equivocal results, ${ }^{7-8}$ although Turner's report showed that specific coagulation deficits could be corrected but had no effect on mortality. ${ }^{9}$

Our results showed that infusions of fresh frozen plasma have a beneficial effect in the prevention of intraventricular haemorrhage without any noticeable effect on mortality. In accord with Johnson et $a l,{ }^{17}$ we were unable to show any lasting improvement in the coagulation variables measured due to infusions of fresh frozen plasma. The beneficial effects of fresh frozen plasma may, therefore, be exerted by a mechanism other than the improvement of coagulation factor concentrations.

The association among unstable blood pressure traces, variable cerebral blood flow, and intraventricular haemorrhage has been well documented, ${ }^{12}$ and profound changes in blood pressure are used as a model in beagle puppies to produce intraventricular haemorrhage. ${ }^{18}$ Fresh frozen plasma may exert its effect by stabilising the circulation and thus preventing rapid changes in blood pressure. Although this is a feasible explanation, the number of babies who were paralysed because of unstable blood pressures was the same in both groups. 
Follow up studies have shown that infants who survive the more severe grades of intraventricular haemorrhage have only a $20 \%$ chance of being normal on follow up. ${ }^{19-21}$ Although we showed that the incidence of intraventricular haemorrhage was reduced by treatment with fresh frozen plasma, we do not know if it alters the neurological outcome for these infants. Treatment with fresh frozen plasma and other agents described previously ${ }^{14-16}$ may only remove the marker of a neurological insult instead of preventing the insult itself. Long term follow up of our population and those of other studies will answer this question.

Our results, and those of others ${ }^{4-6}$ showed that coagulation abnormalities are common in preterm infants. Fresh frozen plasma infusions reduced the incidence of intraventricular haemorrhage from $41 \%$ to $14 \%$ in infants less than 32 weeks' gestation, and we therefore recommend its routine use as a prophylaxis for this disorder. A trial of treatment with fresh frozen plasma and another plasma expanding agent will determine whether the beneficial effect described here occurs by the coagulation system or by action on the stability of the circulation.

We thank the medical and nursing staff of the neonatal intensive care unit, without whose help this study would not have been possible, and Angela Hartup for secretarial work and typing the manuscript.

\section{References}

${ }^{1}$ Volpe JJ. Neonatal intraventricular hemorrhage. $N$ Engl J Med 1981;304:886-91.

2 Tarby TJ, Volpe JJ. Intraventricular hemorrhage in the premature infant. Pediatr Clin North Am 1982;29:1077-1104.

${ }^{3}$ Beverley DW, Chance GW, Coates CF. Intraventricular haemorrhage-timing of occurrence and relationship to perinatal events. Br J Obstet Gynaecol 1984;91:1007-13.

${ }^{4}$ Setzer ES, Webb IB, Wassenaar JW, Reeder JD, Mehta PS, Eitzman DV. Platelet dysfunction and coagulopathy in intraventricular hemorrhage in the premature infant. $J$ Pediatr 1982;100:599-605.

5 Beverley DW, Chance GW, Inwood MJ, Schaus M, O'Keefe B. Intraventricular haemorrhage and haemostasis defects. Arch Dis Child 1984;59:444-8.
${ }^{6}$ McDonald MM, Johnson ML, Rumack CM, et al. Role of coagulopathy in newborn intracranial hemorrhage. Pediatrics 1984;74:26-31.

${ }^{7}$ Gray OP, Ackerman A, Fraser AJ. Intracranial haemorrhage and clotting defects in low birth weight infants. Lancet 1968;i:545-8.

${ }^{8}$ Thomas DB, Burnard ED. Prevention of intraventricular haemorrhage in babies receiving artificial ventilation. Med $J$ Aust 1973;1:933-6.

9 Turner, T, Prowse CV, Prescott RJ, Cash JD. The clinical trial of early detection and correction of haemostatic defects in selected high risk infants. Br J Haematol 1981;47:65-75.

${ }^{10}$ Papile L, Burstein J, Burstein R, Koffler H. Incidence and evolution of subependymal hemorrhage: a study of infants with birth weight less than 1500 grams. J Pediatr 1978;92:529-34.

" Hittner HM, Godio LB, Rudolph AJ, et al. Retrolental fibroplasia: efficacy of vitamin $\mathrm{E}$ in a double blind clinical study of pre term infants. $N$ Engl $J$ Med 1981;305:1365-71.

12 Perlman JM, McMenamin JB, Volpe JJ. Fluctuating cerebral blood flow velocity in respiratory distress syndrome: relation to the development of intraventricular hemorrhage. $N$ Engl J Med 1983;309:204-9.

13 Babcock DS. Neurosonography. Seminars in Ultrasound 1982;3:182-248.

14 Donn SM, Roloff DW, Goldstein GW. Prevention of intraventricular haemorrhage in pre term infants by phenobarbitone. Lancet 1981;ii:215-7.

15 Morgan MEI, Benson JWT, Cooke RWI. Ethamsylate reduces the incidence of periventricular haemorrhàge in very low birth weight babies. Lancet 1981;ii:830-1.

16 Chiswick ML, Johnson M, Woodhall C, et al. Protective effect of vitamin $\mathrm{E}$ against intraventricular haemorrhage in premature babies. Br Med J 1983;287:81-4.

17 Johnson CA, Snyder MS, Weaver RL. The effects of fresh frozen plasma infusions on coagulation screening tests in neonates. Arch Dis Child 1982;57:950-2.

18 Ment LR, Stewart WB, Scott DT, Duncan CC. Beagle puppy model of intraventricular hemorrhage: randomized indomethacin prevention trial. Neurology 1983;33:179-84.

19 Krishnamoorthy KS, Shannon DC, DeLong GR, Todres D, Davies KR. Neurological sequelae in survivors of neonatal intraventricular hemorrhage. Pediatrics 1979;64:233-7.

20 Shankaran S, Slovis TL, Bedard MP, Poland RL. Sonographic classification of intracranial hemorrhage. A prognostic indicator of mortality, morbidity and short term neurological outcome. J Pediatr 1982;100:469-75.

21 Papile LA, Munsich-Bruno G, Shaefer A. Relationship of cerebral intraventricular hemorrhage and early child $\bar{d}$ hood neurological handicaps. J Pediatr 1983;103:273-7.

Correspondence to Dr D Beverley, Regional Neonatal Medical and Surgical Unit, General Infirmary at Leeds, Leeds LS2 9NS.

Received 8 February 1985 